\title{
ANTIQUITY
}

distinction between procedural and processual models is a doubtful one. The archaeologist's procedure depends essentially upon the view of culture and culture process-the framework model--which he employs. And often-as the use of computers in archaeology is teaching usthe framework model is in turn influenced by developments in archaeological procedure.

\section{A Visit to William Cunnington's Museum at Heytesbury in 1807}

We are indebted to Mr L. V. Grinsell, Curator of Archaeology in the Bristol City Museum, for sending us this interesting note.

The celebrated 'Stourhead Collection', which is largely made up of the collection of grave-groups from Wiltshire barrows opened by Sir Richard Colt Hoare and William Cunnington, was in fact originally housed in a summer-house at the bottom of the garden of William Cunnington's house at Heytesbury. The Guide Catalogue published in 1964 contains an account of this summer-house, written by William Cunnington's daughter Elizabeth [ $\mathrm{r}$ ]. From this one is left wondering whether the collection remained for any length of time in a building that sounds anything but waterproof, or whether as the collection grew it might have been moved into the house. William Cunnington died in r8ro, but the collection of antiquities was not transferred to Stourhead until I818. It remained there until 1878 when it was transferred to Devizes.

On $17^{\text {th }}$ November 1807 , the collection at Heytesbury was inspected by Richard Fenton, whose visit is described in his anonymously published Tour in Quest of Genealogy though Several Parts of Wales, Somersetshire, and Wiltshire, in a Series of Letters to a Friend in Dublin (18I ). His account (pp. 25I-5) follows:

Deadford Inn, November 17, 1807 . [Deptford Inn, near Wylye.]

\section{My dear Charles,}

BREAKFAST over at Warminster, ... we lost no time to make for Heytesbury, no great distance off, and were no sooner alighted than we called to see the museum, containing the contents of the different tumuli that have been opened for these ten years, under the patronage of Sir Richard Hoare, and the direction of Mr Cunnington, who has the care and the management of it. This gentleman, who has all the enthusiasm that is necessary to excite the mind to a pursuit of this sort, appeared to be highly gratified by our visit, as well as the zeal we expressed at the prospect of a new epoch in antiquarian literature, from the splendid work Sir Richard Hoare had in contemplation [2]. Nothing could be more curious and systematic than the arrangement of the museum: the contents of every tumulus was separate, and the articles so disposed as in the case of ornaments, such as beads, in such elegant knots and festoons, as to please the eye which looks to nothing farther. The story of several was so perfectly told by the relics they contained, that an epitaph could not have let us more into the light of the rank and character of the dead. In one drawer were displayed all the utensils employed to fabricate arrow-heads, other weapons and implements that required sharp points, there being various whetstones, of a coarse and a finer grit, with grooves in each, worn down by the use made of them; together with bone in its wrought and unwrought state, evidently proving it to have been the sepulture of an artist, whose employ this was. In another we were shown some flint arrow-heads, very similar to those I saw at Milford, which had been dug out of a turbary in the island of Nantucket, which Mr Cunnington accompanied with the history of the tumulus wherein they lay. About three feet from the apex of the barrow, in digging they came to the skeleton of a $\mathrm{dog}$, and from the fineness of the bones supposed to be of the greyhound kind; but when they got to the level of the surrounding ground (where, in general, the interment is found), in the centre, on the ancient sward then apparent, they came to a heap of ashes, mixed with some few particles of bone, not perfectly calcined, as is always the case, and surrounded by a wreath of stag's horns. In the middle of the ashes were discovered the flint arrow-heads, and a curious 


\section{NOTES AND NEWS}

pebble of a reddish colour, not casual, but certainly placed there with design, as in that chalk country a pebble of such a character and quality is never seen, probably some amulet. What a beautiful designation of the hunter's grave! [3] He told us they met with groups of tumuli sometimes of the prince or chieftain, and all his household, the prince's chiefly larger, but clearly characterized by the richness and singularity of the ornaments and relics; and many of the others as characteristic of the person whose ashes occupied them. They never find coin in any, which induces me to think that the greater part are prior to the era of mintage; and seldom have found ornaments of gold [4]. We saw a variety of urns from the height of two feet to one not twice as big as a thimble. The urns that held the remains of the dead were all rude pottery, and half baked; but there are found often accompanying skeletons, a vessel they have given the name of drinking cup to; I presume from a supposition, that it was filled with some fluid, a viaticum for the dead, as it is always near the head of the skeleton, with its mouth up, and empty. The pottery of these smaller urns is much thinner, better baked, and more ornamented. When Sir Richard Hoare opens tumuli, a week is generally set apart for the operations, and the Baronet, he told us, is generally attended by a party of his friends; their headquarters are sometimes at Amesbury, sometimes at Everley, sometimes at Woodyeates Inn; 'and in such a company, gentlemen', said he, 'you may well suppose the time passes with much festivity and good humour; though they may not all of them be as sanguine barrowhunters as the learned Baronet, yet they are all amateurs in such a degree as to relish the pursuit, and enjoy it'.... It was not only the things we saw, so totally new to us, that we were so much delighted with; Mr Cunnington's illustrative account of the different articles displayed very considerable powers of mind, as well as originality, and was conveyed in a language and a manner peculiarly his own, and left us in admiration of acquirements so rarely met with in men of his rank and calling, who affected no other character than that of a respectable tradesman.

[1] Annable, F. K. and Simpson, D. D. A. Guide Catalogue of the Neolithic and Bronze Age Collections in Devizes Museum (Devizes, 1964), p. 5 .

[2] The first volume of Sir Richard Colt Hoare's Ancient Wiltshire was published in 1810.

[3] 'The Hunter's Barrow', Collingbourne Kingston no. 19. Ancient Wiltshire, I, 183 .

[4] For a recent study of the finding of coins and gold in barrows, see $\mathrm{C}$. V. Grinsell, 'Barrow Treasure, in Fact, Tradition, and Legislation', Folklore, LXXVIII, $1967, x-38$.

\section{An Exhibition of Neolithic Material from Yugoslavia}

A selection of material representing the Starčevo and subsequent Vinča cultures of the Central Balkans is the subject of a special exhibition The Arts of the First Farmers arranged by the Sheffield City Museums. It will be open to the public there from the end of March to $4^{\text {th }}$ May.

This important selection of Neolithic material has been drawn from a number of museum collections in Yugoslavia and originally formed the larger part of the summer exhibition held in the National Museum in Belgrade last year. It is the first time that much of this material will be seen in Britain and little of it has been published in the English language. A well illustrated catalogue is being produced and this will include a survey of the Serbian Neolithic by Dr Colin Renfrew of the University of Sheffield.

We are particularly grateful to the National Museum in Belgrade for giving the British public this opportunity of seeing such a rich and important exhibition. The exhibition will also be shown at the British Museum for a month from 12 th May and probably at two other museums before returning to Yugoslavia at the end of August.

GEOFFREY LEWIS 